University of Nebraska - Lincoln

DigitalCommons@University of Nebraska - Lincoln

USDA National Wildlife Research Center - Staff Publications
U.S. Department of Agriculture: Animal and Plant Health Inspection Service

July 2007

\title{
Demographics of Black Vultures in North Carolina
}

\author{
Bradley F. Blackwell
}

USDA/APHIS/WS National Wildlife Research Center, bradley.f.blackwell@aphis.usda.gov

Michael L. Avery

United States Department of Agriculture, Animal and Plant Health Inspection Service, Wildlife Services, National Wildlife Research Center, michael.I.avery@aphis.usda.gov

Bryan D. Watts

The Center for Conservation Biology, College of William \& Mary

Martin S. Lowney

United States Department of Agriculture, Animal and Plant Health Inspection Service, Wildlife Services, Mosely, VA

Follow this and additional works at: https://digitalcommons.unl.edu/icwdm_usdanwrc

Part of the Environmental Sciences Commons

Blackwell, Bradley F.; Avery, Michael L.; Watts, Bryan D.; and Lowney, Martin S., "Demographics of Black Vultures in North Carolina" (2007). USDA National Wildlife Research Center - Staff Publications. 681. https://digitalcommons.unl.edu/icwdm_usdanwrc/681

This Article is brought to you for free and open access by the U.S. Department of Agriculture: Animal and Plant Health Inspection Service at DigitalCommons@University of Nebraska - Lincoln. It has been accepted for inclusion in USDA National Wildlife Research Center - Staff Publications by an authorized administrator of DigitalCommons@University of Nebraska - Lincoln. 


\title{
Demographics of Black Vultures in North Carolina
}

\author{
BRADLEY F. BLACKWELL, ${ }^{1}$ United States Department of Agriculture, Animal and Plant Health Inspection Service, Wildlife Services, National \\ Wildife Research Center, Obio Field Station, 6100 Columbus Avenue, Sandusky, OH 44870, USA \\ MICHAEL L. AVERY, United States Department of Agriculture, Animal and Plant Health Inspection Service, Wildife Services, National Wildlife \\ Research Center, Florida Field Station, 2820 East University Avenue, Gainesville, FL 32641, USA \\ BRYAN D. WATTS, The Center for Conservation Biology, College of William E Mary, P.O. Box 8795, Williamsburg, VA 23187-8795, USA \\ MARTIN S. LOWNEY, ${ }^{2}$ United States Department of Agriculture, Animal and Plant Health Inspection Service, Wildife Services, P.O. Box 130, Mosely, \\ VA 23120, USA
}

\begin{abstract}
Understanding the contributions of vital rates to species population growth is critical to developing new management protocols. We constructed a model population for black vultures (Coragyps atratus) in North Carolina, USA, based on demographic data from a 14-year study. The model population was similar in stage structure to the reference population, and adult survival was the primary contributor to the annual rate of increase $(10.6 \%)$. We suggest that the North Carolina black vulture population is experiencing high rates of survival and fertility, potentially breeding at an age younger than previously assumed, and growing rapidly. (JOURNAL OF WILDLIFE MANAGEMENT 71(6):1976-1979; 2007)
\end{abstract}

DOI: $10.2193 / 2006-146$

KEY WORDS black vulture, Breeding Bird Survey, human-wildlife conflicts, matrix population model, population demographics, species management.

Once considered the most common bird of prey in the western hemisphere (Brown and Amadon 1968), the black vulture (Coragyps atratus) thrives today, with the total population estimated to be 20 million birds (Rich et al. 2004). Long-term population trend data from the Christmas Bird Count and the Breeding Bird Survey (BBS) databases indicate widespread and consistent increases in populations of the black vulture throughout the United States (Sauer et al. 1996, 2005; Avery 2004). Also, United States black vulture populations have expanded their range since the 1940s, extending north into Ohio and northeastward into southern New England (Greider and Wagner 1960, Buckley 1999).

Increases and range expansion by black vulture populations represent a conservation victory for a species recently believed in decline (Rabenold and Decker 1990, Buckley 1999). However, the species' success also presents new challenges for wildlife managers as black vultures increasingly interact with human activities. Major areas of conflict include livestock depredations (Lowney 1999, Avery and Cummings 2004), property damage (Lowney 1999), and collisions with aircraft (DeVault et al. 2005, Blackwell and Wright 2006).

Some instances of black vulture damage have led to illegal killing (e.g., Holt 1998). However, most problems caused by black vultures are resolved using nonlethal methods (Avery et al. 2002, Seamans 2004). The affected birds are displaced, but they remain part of the local black vulture population, shift to alternate roost sites, and conceivably contribute to new problem situations. Therefore, effective integrated vulture management plans might include population reduction as a component (Humphrey et al. 2004).

An important aspect of any species management program,

${ }^{1}$ E-mail: bradley.f.blackwell@aphis.usda.gov

2 Present address: 1930 Route 9, Castleton, NY 12033-9653, USA particularly one that considers managed population reduction in light of possible illegal killing, is an understanding of how a population responds to changes in vital rates. Simulation modeling is frequently used for evaluating responses of wild bird populations to management alternatives (Blackwell et al. 2003, Brook et al. 2003, Watola et al. 2003). The accuracy of simulation models and subsequent population projections are largely dependent upon the extent of demographic data available for the target species, such as age-specific survival and fecundity, and age distribution.

We know, for example, that the black vulture is a longlived species (potentially $>20 \mathrm{yr}$ ) exhibiting delayed maturation to breeding status, monogamy, and long-term pair bonds (Buckley 1999). However, age-specific survival data are few. Rabenold (1986) reports survival rates of 0.46$0.93>2$ months postfledging for birds in North Carolina, USA. Unmarked vultures in North Carolina were captured in walk-in funnel traps (Rabenold 1986) and aged, relative to facial morphology, as juvenile, subadult, or adult (Rabenold and Decker 1990). Still, subadult survival rates remain uncertain. Parmalee and Parmalee (1967) recovered $52 \%$ of banded individuals within 2 years of banding (agespecific banding data were not reported). Annual adult survival (based on disappearance of marked breeders and from known nest sites and pairings of marked breeders with new mates) ranged from $87.5 \%$ (Rabenold 1986) to $90.6 \%$ (Rabenold and Decker 1990).

Also, Parker et al. (1995) reported a single known-age black vulture breeding for the first time at age 8 years. Because investigators were not able to document the yearly breeding activities of every bird in the study population, prior breeding by individuals assigned to subadult and adult stages was unknown (P. Parker, University of Missouri-St. Louis, personal communication). Thus, age-at-first-breeding remains unknown for the black vulture. 
Table 1. Fertility $\left(F_{\text {stage }}\right)^{\mathrm{a}}$ and survival $\left(S_{\text {stage }}\right)^{\mathrm{a}}$ estimates composing 8 - and 5 -stage projection matrices for female black vultures in North Carolina, USA.

\begin{tabular}{ccc}
\hline \multirow{2}{*}{$\begin{array}{c}\text { Vital rate } \\
\text { estimate }\end{array}$} & \multicolumn{2}{c}{ Value } \\
\cline { 2 - 3 } & 8-stage matrix & 5-stage matrix \\
\hline$F_{5+}$ & & 0.4987 \\
$F_{8+}$ & 0.4987 & 0.8750 \\
$S_{1}$ & 0.8905 & 0.8905 \\
$S_{2}$ & 0.8905 & 0.8905 \\
$S_{3}$ & 0.8905 & 0.9060 \\
$S_{4}$ & 0.8905 & 0.9060 \\
$S_{5+}$ & 0.8905 & \\
$S_{6}$ & 0.9060 & \\
$S_{7}$ & 0.9060 & \\
$S_{8+}$ & & \\
\hline
\end{tabular}

${ }^{\text {a }}$ Fertility estimates comprise the product of stage-specific proportion of $\mathrm{F}$ breeding, $\bar{x}$ no. of $\mathrm{F}$ young/ $\mathrm{F}$ breeder, and survival from fledging to just before age $1 \mathrm{yr}\left(S_{0}\right)$. Subadult fertility estimates equal zero in both matrices. Composite fertility values for breeding-age $\mathrm{F}$ in each matrix noted as $F_{5+}$ (5-stage matrix) or $F_{8+}$ (8-stage matrix). Composite survival values for breeding-age $\mathrm{F}$ in each matrix noted as $S_{5+}$ (5-stage matrix) or $S_{8+}$.

However, females from Old World vulture species might breed by as early as age 5 years (e.g., cape vulture [Gyps coprotheres; Robertson 1983, 1984]; griffon vulture [Gyps fulvus; Blanco and Martinez 1996]). Relative to Ciconiiformes, in which the black vulture is now grouped (American Ornithologists' Union 1998), wood storks (Mycteria americana) begin breeding by ages 3 years and 4 years (Coulter et al. 1999), and white storks (Ciconia ciconia) can breed by age 3 years (Tortosa et al. 2002). Moreover, Tortosa et al. (2002) note that human-based food resources contribute to lower breeding ages in white storks.

In addition, the black vulture generally produces 2 eggs (Buckley 1999), with fledgling production varying depending upon nest location $(\bar{x}=0.73$ fledglings/nest in rock crevices in PA and MA, USA [Coleman and Fraser 1989]; 1.29 fledglings/nest in NC, generally in abandoned buildings [Rabenold and Decker 1990]). Censuses of winter roosts in North Carolina yielded counts of 580 birds (10 censuses during winter 1979-1980) and 636 birds (9 censuses during Jan 1990), with subadults composing $37 \%$ and $18 \%$ of the counts, respectively (Rabenold and Decker 1990).

Despite a wealth of published research, longitudinal data for black vulture populations are few; thus, contributions of vital rates, particularly annual variances, to the dynamics of the species' populations are unclear. Our objectives were to 1) construct a baseline population model for black vultures by referencing values for vital rates derived from a 14-year study in North Carolina (Rabenold 1986, Rabenold and Decker 1990, Parker et al. 1995); 2) evaluate the structure of the model population relative to field estimates; and 3) estimate contributions of matrix elements to rate of population growth.

\section{STUDY AREA}

We referenced demographic data on black vultures collected in the Piedmont of central North Carolina, Chatham County, near Silk Hope $\left(35^{\circ} 47^{\prime} \mathrm{N}, 79^{\circ} 22^{\prime} \mathrm{W}\right)$, from 1977 through 1990 (see Rabenold 1986, Rabenold and Decker 1990, Parker et al. 1995).

\section{METHODS}

We used the aforementioned published data to construct a stage-classified deterministic matrix model comprising females only. Specifically, a stage-classified model differs from an age-classified model in that a stage may comprise individuals differing in age but sharing factors (e.g., breeding experience) known to affect vital rates (Caswell 2001). Because of limited information on the survival of subadult birds, uncertainties as to age-at-first-breeding, and evidence from other vulture species that individuals might, given adequate resources, breed by age 4 years or 5 years, we constructed 2 models. We followed methods for matrix models as described by Caswell (2001) and adhered closely to species-specific applications of deterministic matrix models (e.g., Mertz 1971, Meretsky et al. 2000, Blackwell et al. 2003).

We defined our first model black vulture population as age specific through stage 7 , with stage 8 comprising birds about to turn age 8 years and older. The resulting stage-classified matrix comprised fertility elements for birds about to turn age 1 year $\left(F_{1}\right)$ through the adult stage $\left(F_{8+}\right)$, on the first row. Stage 8 comprised potential breeders. We assumed a prebreeding census (e.g., tracking the first age class from being almost age $1 \mathrm{yr}$ until they are almost age $2 \mathrm{yr}$ ) and thus incorporated the effects of first-year mortality into the fertility coefficients (Caswell 2001; see below). Stage-specific survival rates based on data for breeding pairs (Rabenold 1986, Rabenold and Decker 1990) composed subsequent rows of the projection matrix (i.e., forming the diagonal). Here, survival rates for subadults $\left(S_{1}-S_{7}\right)$ were unavailable; therefore, we assumed the minimum reported value for $S_{1}$, the mean of reported values for $S_{2}$ through $S_{6}$, and the maximum value reported for the last 2 stages of each matrix (Table 1).

Similarly, we defined our second model population as agespecific through stage 4 , with stage 5 comprising birds about to turn age 5 years and older. The resulting stage-classified matrix comprised fertility elements for birds about to turn age 1 year $\left(F_{1}\right)$ through the adult stage $\left(F_{5+}\right)$, on the first row. Here, because of evidence that other vulture species (noted above) breed by age 4 years or 5 years, we defined stage 5 as comprising potential breeders. Again, we assumed a prebreeding census. Also, as in the 8-stage matrix, we referenced survival rates reported for breeding pairs (Rabenold 1986, Rabenold and Decker 1990) to compose rates for subadults. We assumed the minimum reported survival value for $S_{1}$, the mean of reported values for $S_{2}$ and $S_{3}$, and the maximum value reported for the last 2 stages of each matrix (Table 1).

In both models, fertility is related to the age-specific proportion of females breeding $\left(P B_{s}\right)$, mean number of female young fledged per female (assuming a 1:1 sex ratio; $\mathrm{Fl}_{s}$ ), and survival of young from fledging to just before age 1 year $\left(S_{0}\right)$ as

$$
F s=P B_{s} F l_{s} S_{0}
$$


Table 2. Stable age distribution, reproductive value, and elasticity of stagespecific fertility (only birds age $\geq 8 \mathrm{yr}$ assumed to breed) and survival elements of a stage-based matrix population model for female black vultures in North Carolina, USA, assuming a prebreeding census, that exhibits an exponential rate of $5.5 \%$.

\begin{tabular}{lcccc}
\hline & $\begin{array}{c}\text { Stable age } \\
\text { Stage }\end{array}$ & $\begin{array}{c}\text { Reproductive } \\
\text { distribution }\end{array}$ & Ealue & Elasticity \\
\cline { 4 - 5 } & & Fertility & Survival \\
\hline 1 & 0.1539 & 1.00 & 0.0000 & 0.0713 \\
2 & 0.1274 & 1.21 & 0.0000 & 0.0713 \\
3 & 0.1074 & 1.43 & 0.0000 & 0.0714 \\
4 & 0.0905 & 1.70 & 0.0000 & 0.0714 \\
5 & 0.0763 & 2.02 & 0.0000 & 0.0713 \\
6 & 0.0643 & 2.39 & 0.0000 & 0.0713 \\
7 & 0.0542 & 2.84 & 0.0000 & 0.0713 \\
$8+$ & 0.3260 & 3.31 & 0.0713 & 0.4293 \\
\hline
\end{tabular}

${ }^{a}$ Scaled proportionately.

b Proportional sensitivity for stage-specific vital rates; values rounded but sum approximately to unity (Caswell et al. 1984, de Kroon et al. 1986).

(Table 1). We arbitrarily assumed that not all breeding-age females would breed (i.e., $P B_{s}=0.99$ ), assigned the number of female young per female breeder as the mean of published values $\left(F l_{s}=0.645\right.$; Rabenold and Decker 1990), and assumed $S_{0}$ to be the weighted average for individuals surviving $>2$ months $(0.781$; as reported by Rabenold 1986).

We next calculated the proportional change in the finite rate, $\lambda$, resulting from a proportional change in a vital rate, $a_{i j}$, (i.e., proportional sensitivities or elasticities; Caswell et al. 1984, de Kroon et al. 1986), as

$$
e_{i j}=\frac{a_{i j}}{\lambda} \frac{\partial \lambda}{\partial a_{i j}} .
$$

Here, the sensitivity of $\lambda$ to changes in $a_{i j}$ is proportional to the product of the $i$ th element of the reproductive value vector (the left eigenvector) and the $j$ th element of the stable age distribution (the right eigenvector associated with the dominant eigenvalue, $\lambda$; see also Caswell 2001). We used MATLAB (Version 5.3.29215a, Release 11.1; The Math Works, Inc., Natick, MA) to calculate the reproductive value vector and stable age distribution, as well as elasticities. For clarity, we report model population growth as the exponential rate (see Caughley 1977, Caswell 2001).

\section{RESULTS}

The 8-stage-model black vulture population increased approximately 5.5\% annually. Subadults (age 2-7 yr) composed $52.0 \%$ of the population, followed by adults (age $\geq 8 \mathrm{yr} ; 32.6 \%$ ), and juveniles (15.4\%; Table 2). Because of the single breeding stage, reproductive values indicate no senescence. The proportional contribution of adult survival to the model population rate of increase was $>6$ times that of other stage-specific rates (Table 2).

In contrast, the 5-stage-model black vulture population increased approximately $10.6 \%$ annually. Adults (age $\geq 5 \mathrm{yr}$ ) composed $43.3 \%$ of the population, followed by subadults (age 2-4 yr; 37.3\%), and juveniles (19.4\%; Table 3). As in the 8 -stage model, reproductive values increase through the
Table 3. Stable age distribution, reproductive value, and elasticity of stagespecific fertility (only birds age $\geq 5 \mathrm{yr}$ only assumed to breed) and survival elements of a stage-based matrix population model for female black vultures in North Carolina, USA, assuming a prebreeding census, that exhibits an exponential rate of $10.6 \%$.

\begin{tabular}{lcccc}
\hline & $\begin{array}{c}\text { Stable age } \\
\text { Stage }\end{array}$ & $\begin{array}{c}\text { Reproductive } \\
\text { distribution }\end{array}$ & value & Elasticity \\
\cline { 4 - 5 } & & & Fertility & Survival \\
\hline 1 & 0.1941 & 1.00 & 0.0000 & 0.1063 \\
2 & 0.1528 & 1.27 & 0.0000 & 0.1063 \\
3 & 0.1224 & 1.59 & 0.0000 & 0.1063 \\
4 & 0.0981 & 1.98 & 0.0000 & 0.1063 \\
$5+$ & 0.4326 & 2.43 & 0.1063 & 0.4687 \\
\hline
\end{tabular}

${ }^{\text {a }}$ Scaled proportionately.

b Proportional sensitivity for stage-specific vital rates, values rounded but sum approximately to unity (Caswell et al. 1984, de Kroon et al. 1986).

breeding stage. The proportional contribution of adult survival to the model population rate of increase was $>4$ times that of other stage-specific rates (Table 3 ).

\section{DISCUSSION}

By limiting the model black vulture population to breeding by age 8 years, we found that the stage composition was not comparable to the North Carolina data (Rabenold and Decker 1990). However, the composition of our 5-stagemodel population was similar to indices reported from separate censuses conducted at winter roosts in North Carolina, where subadults composed $18 \%$ to $37 \%$ of counts (Rabenold and Decker 1990). Also, the annual rate of increase generated by the 5 -stage model $(10.6 \%)$ is similar to the post-DDT era BBS population trend for black vultures in North Carolina $(\bar{x}$ change/yr $=9.9 \%, P=0.04, \bar{x}$ count $/$ route $=0.92$ birds, $n=27$ routes, 1977-2005; Sauer et al. 2005).

Notably, the life-history parameters used in both models were contemporary to opinions concerning the possible decline of black vulture populations in the Southeast, including populations in North Carolina (Stewart 1984, Rabenold and Decker 1990; see also Buckley 1999). Loss of high-quality nest sites and eggshell thinning were noted as possible regulatory factors in black vulture populations (Jackson 1983, Kiff et al. 1983, Rabenold and Decker 1990). However, we found that the proportional contribution to population growth rate by adult survival, in both models, far exceeded the contribution of fertility. We suggest, therefore, that the black vulture population in North Carolina, and likely populations elsewhere, is experiencing high rates of survival and fertility, potentially breeding at an age younger than previously assumed, and growing rapidly.

\section{MANAGEMENT IMPLICATIONS}

New field efforts should be undertaken to quantify population demographic parameters for black vultures, particularly age structure and age-at-first-breeding, and to determine seasonal movement patterns to quantify the effect of immigration on local population density. We encourage the use of this model, and derivations based on new data, by agencies seeking to understand and accurately project trends 
in local and regional black vulture populations relative to potential management scenarios.

\section{ACKNOWLEDGMENTS}

We greatly appreciate the helpful insights of J. Coleman and P. Parker relative to the data used in model construction, and their reviews of the manuscript. We also thank $\mathrm{R}$. Beason, P. Kocovsky, and T. Seamans, for their reviews of earlier drafts of this manuscript. E. Poggiali provided logistical support.

\section{LITERATURE CITED}

American Ornithologists' Union. 1998. Check-list of North American birds. Seventh edition. American Ornithologists' Union, Washington, D.C., USA.

Avery, M. L. 2004. Trends in North American vulture populations. Proceeding of the Vertebrate Pest Conference 21:116-121.

Avery, M. L., and J. L. Cummings. 2004. Livestock depredations by black vultures and golden eagles. Sheep and Goat Research Journal 19:58-63.

Avery, M. L., J. S. Humphrey, E. A. Tillman, K. O. Phares, and J. E. Hatcher. 2002. Dispersing vulture roosts on communication towers. Journal of Raptor Research 36:45-50.

Blackwell, B. F., E. Huszar, G. Linz, and R. A. Dolbeer. 2003. Lethal control of red-winged blackbirds to manage damage to sunflower: an economic evaluation. Journal of Wildlife Management 67:818-828.

Blackwell, B. F., and S. E. Wright. 2006. Collisions of red-tailed hawks (Buteo jamaicensis), turkey (Cathartes aura), and black vultures (Coragyps atratus) with aircraft: implications for bird strike reduction. Journal of Raptor Research 40:76-80.

Blanco, G., and F. Martinez. 1996. Sex difference in breeding age of griffon vultures (Gyps fulvus). Auk 113:247-248.

Brook, B. W., N. S. Sodhi, M. C. K. Soh, and H. C. Lim. 2003. Abundance and projected control of invasive house crows in Singapore. Journal of Wildlife Management 67:808-817.

Brown, L., and D. Amadon. 1968. Eagles, hawks and falcons of the world. McGraw-Hill, New York, New York, USA.

Buckley, N. J. 1999. Black vulture (Coragyps atratus). Account 411 in A. Poole and F. Gill, editors. The birds of North America. The Birds of North America, Philadelphia, Pennsylvania, USA.

Caswell, H. 2001. Matrix population models: construction, analysis, and interpretation. Sinauer, Sunderland, Massachusetts, USA.

Caswell, H., R. Naiman, and R. Morin. 1984. Evaluating the consequences of reproduction in complex salmonid life cycles. Aquaculture 43:123-143.

Caughley, G. 1977. Analysis of vertebrate populations. John Wiley and Sons, Brisbane, Australia.

Coleman, J. S., and J. D. Fraser. 1989. Habitat use and home ranges of black and turkey vultures. Journal of Wildlife Management 53:782-792.

Coulter, M. C., J. A. Rodgers, J. C. Ogden, and F. C. Depkin. 1999. Wood stork (Mycteria americana). Account 409 in A. Poole and F. Gill, editors. The birds of North America. The Birds of North America, Philadelphia, Pennsylvania, USA.

de Kroon, H., A. Plaisier, J. van Groenendael, and H. Caswell. 1986. Elasticity: the relative contribution of demographic parameters to population growth rate. Ecology 67:1427-1432.

DeVault, T. L., B. D. Reinhart, I. L. Brisbin, Jr., and O. E. Rhodes, Jr. 2005. Flight behavior of black and turkey vultures: implications for reducing bird-aircraft collisions. Journal of Wildlife Management 69: 592-599.

Greider, M., and E. S. Wagner. 1960. Black vulture extends breeding range northward. Wilson Bulletin 72:291.

Holt, M. 1998. Black vulture fatalities: Botetourt County. Report of investigation. U.S. Department of the Interior, Fish and Wildlife Service, Richmond, Virginia, USA.

Humphrey, J. S., E. A. Tillman, and M. L. Avery. 2004. Vulture-livestock interactions at a central Florida cattle ranch. Proceedings of the Vertebrate Pest Conference 21:122-125.

Jackson, J. A. 1983. Nesting phenology, nest site selection, and reproductive success of black and turkey vultures. Pages 245-270 in A. Wilbur and J. A. Jackson, editors. Vulture biology and management. University of California Press, Berkeley, USA.

Kiff, L. F., D. B. Peakall, M. L. Morrison, and S. R. Wilbur. 1983 Eggshell thickness and DDE residue levels in vulture eggs. Pages 440458 in A. Wilbur and J. A. Jackson, editors. Vulture biology and management. University of California Press, Berkeley, USA.

Lowney, M. S. 1999. Damage by black and turkey vultures in Virginia, 1990-1996. Wildlife Society Bulletin 27:715-719.

Meretsky, V. J., N. F. R. Snyder, S. R. Beissinger, D. A. Clendenen, and J. W. Wiley. 2000. Demography of the California condor: implications for reestablishment. Conservation Biology 14:957-967.

Mertz, D. B. 1971. The mathematical demography of the California condor population. American Naturalist 105:437-453.

Parker, P. G., T. A. Waite, and M. D. Decker. 1995. Kinship and association in communally roosting black vultures. Animal Behavior 49: 395-401.

Parmalee, P. W., and B. G. Parmalee. 1967. Results of banding studies of the black vulture in eastern North America. Condor 69:146-155.

Rabenold, P. P. 1986. Family associations in communally roosting black vultures. Auk 103:32-41.

Rabenold, P. P., and M. D. Decker. 1990. Black vultures in North Carolina: statewide population surveys and analysis of Chatham County population trends. Final report, North Carolina Wildlife Resources Commission, Nongame and Endangered Wildlife Program, Contract 1989SG07, Raleigh, USA.

Rich, T. D., C. J. Beardmore, H. Berlanga, P. J. Blancher, M. S. W. Bradstreet, G. S. Butcher, D. W. Demarest, E. H. Dunn, W. C. Hunter, E. E. Iñigo-Elias, J. A. Kennedy, A. M. Martell, A. O. Panjabi, D. N. Pashley, K. V. Rosenburg, C. M. Rustay, J. S. Wendt, and T. C. Will. 2004. Partners in Flight North American landbird conservation plan. Cornell Laboratory of Ornithology, Ithaca, New York, USA.

Robertson, A. S. 1983. Known-age cape vultures breeding in the wild. Ostrich 54:179.

Robertson, A. S. 1984. Aspects of the population dynamics of cape vultures in the Cape Province. Ostrich 55:196-206.

Sauer, J. R., J. E. Hines, and J. Fallon. 2005. The North American Breeding Bird Survey, results and analysis, 1966-2005. Version 6.2.2006. U.S. Geological Survey, Patuxent Wildlife Research Center, Laurel, Maryland, USA.

Sauer, J. R., S. Schwartz, and B. Hoover. 1996. The Christmas Bird Count home page. Version 95.1. Patuxent Wildlife Research Center, Laurel, Maryland, USA. <http://www.mbr-pwr.usgs.gov/bbs/cbc.html/>. Accessed 6 Jun 2007.

Seamans, T. W. 2004. Response of roosting turkey vultures to a vulture effigy. Ohio Journal of Science 104:136-138.

Stewart, P. A. 1984. Population decline of black vultures in North Carolina. Chat 48:65-68.

Tortosa, F. S., J. M. Caballero, and J. Reyes-López. 2002. Effect of rubbish dumps on breeding success in the white stork in southern Spain. Waterbirds 25:39-43.

Watola, G. V., D. A. Stone, G. C. Smith, G. J. Forrester, A. E. Coleman, J. T. Coleman, M. J. Goulding, K. A. Robinson, and T. P. Milsom. 2003. Analyses of two mute swan populations and the effects of clutch reduction: implications for population management. Journal of Applied Ecology 40:565-579.

Associate Editor: Bechard. 